\title{
ПЕРСПЕКТИВЫ ОЦЕНКИ ЗЕМЕЛЬНЫХ УЧАСТКОВ В РОССИИ
}

\section{Никита Константинович Шевелев}

Сибирский государственный университет геосистем и технологий, 630108, Россия, г. Новосибирск, ул. Плахотного, 10, обучающийся, тел. (383)361-01-09, e-mail: nshevelevv@mail.ru

\section{Елена Викторовна Убоженко}

Сибирский государственный университет геосистем и технологий, 630108, Россия, г. Новосибирск, ул. Плахотного, 10, кандидат экономических наук, доцент кафедры цифровой экономики и менеджмента, тел. (913)472-36-87, e-mail: ewunsk@yandex.ru

В статье проведен анализ развития современных методик оценки земельных участков, выявлены перспективные направления оценочной деятельности в данной области, показаны векторы развития кадастровой и рыночной оценки земельных участков.

Ключевые слова: земельный участок, кадастровая оценка земельного участка, рыночная оценка земельного участка, кадастр недвижимости, земельно-имущественные отношения

\section{TRENDS IN LAND VALUATION IN RUSSIA}

\section{Nikita K. Shevelev}

Siberian State University of Geosystems and Technologies, 10, Plakhotnogo St., Novosibirsk, 630108, Russia, Student, phone: (383)361-01-09, e-mail: nshevelevv@mail.ru

\section{Elena V. Ubozhenko}

Siberian State University of Geosystems and Technologies, 10, Plakhotnogo St., Novosibirsk, 630108, Russia, Ph. D., Head of the Department of Digital Economics and Management, phone: (913)472-36-87, e-mail: ewunsk@yandex.ru

The article contains an analysis of the development of modern land parcel valuation methods, identified promising areas of evaluation activity in this area, and shows the vectors of cadastral and market land parcel valuation development.

Keywords: land plot, cadastral valuation of land plot, market valuation of land plot, real estate cadastre, land-property relations

В статье рассматриваются перспективы оценки земельного участка. Тенденция развития оценочной деятельности неразрывно связана с экономическими факторами, а также с финансовой средой. Рациональное и эффективное использование земельных участков является в настоящее время одним из стратегически важных аспектов политики Российской Федерации в целях создания необходимых условий для стабильного экономического развития государства.

Земельный участок - это определенная часть земной поверхности, которая имеет конкретную границу и площадь, а также местоположение и соответствующий с земельным кадастром правовой статус (целевое назначение, вид разрешенного использования), который отражается в документах государственной регистрации прав на землю [1]. 
Известно, что в России вследствие Октябрьской революции 1917 года понятийный аппарат земельных отношений, а также учет земельных ресурсов сильно изменился - все земли перешли в государственную собственность и таким образом земля не являлась больше объектом налогообложения. На протяжении трех лет, вплоть до 1920 года шел процесс учета и распределения земельных угодий крестьянам и велись землеустроительные работы. Большой толчок развитию кадастра дало Постановление Совмина СССР №2529 «О едином государственном учете земельного фонда СССР», после которого по всей стране масштабно начали составлять атласы и карты, которые описывали сельскохозяйственное производство и другие экономические факторы развития страны [2].

Соответственно государственный земельный кадастр основывается на достоверных сведениях о хозяйственном, а также правовом статусе всех земель, при этом количественно содержит параметры оценки.

Произошедшая очередная земельная реформа 1990 года дала новый вектор развитию кадастра и оценке земельных участков - начался процесс перехода к различным формам собственности на земельные участки, земли очень активно перераспределялись.

В ходе приватизации 1991 года начался процесс ликвидации колхозов и совхозов, когда в них должна была поменяться форма собственности с государственной на частную или коллективно-долевую.

За этим последовало введение арендной платы за земельный участок, налог на землю, а также более активно стал вестись учет разных по категориям и формам собственности земельных участков [3]. Благодаря событиям, связанным с распадом СССР и процессом приватизации, оценка земельных участков претерпела радикальные изменения. Теперь она была нацелена на реформирование правовых отношений на земельные участки и организацию рационального управления земельными ресурсами нового государства - Российской Федерации.

В настоящее время комплексной оценкой земельного участка считается определенная последовательность процедур, которая основывается на законах и методике оценочной деятельности. Таким образом, земельный участок возможно оценить на основе его рыночной и кадастровой стоимости, учитывая правовой статус данного участка, вид разрешенного использования и другие характеристики (географическое расположение, климат, близость к автобусным остановкам и др.) [4].

Из этого следует вывод, что подобная оценка может много где использоваться - в целях продажи, в определении инвестиционной привлекательности участка, в определении налогооблагаемой базы земельного участка и т. д.

Относительно государственной кадастровой оценки земельных участков необходимо выделить несколько важных перспективных направлений. Нередко при использовании метода массовой оценки индивидуальная особенность земельного участка вовсе не учитывается (географическое расположение участка, категория земли, наличие сервитута и др.) [7]. Соответственно, для более точного определения кадастровой оценки начали учитывать индивидуальные параметры земельного участка, а также собственники стали чаще оспаривать кадастровую 
стоимость [6]. Известно, что в кадастровой оценке земельных участков нет единой методики, поэтому необходимо ссылаться на несколько принципов, чтобы избежать неточностей при проведении оценки - принцип прозрачности, эквивалентности, гибкости и баланса. Во многом государственная кадастровая оценка зависит от качества работы государственных исполнительных органов в данной сфере и от эффективности управления. Уже в настоящее время существуют основания для создания методологии и сформирования нового, более справедливого способа оценки, где были бы удовлетворены потребности граждан Российской Федерации в области земельно-имущественных отношений [5].

Для определения рыночной стоимости земельного участка используется множество подходов к оценке, принципов, а также методов. На данный момент во времена информационно-технологической эпохи идет цифровизация и автоматизация множества различных процессов, к этому можно отнести и процесс создания кадастра недвижимости, в частности, определение рыночной цены земельных участков. Если двадцать лет назад, чтобы оценить земельный участок, требовалось затратить значительное количество времени, потому что большей части необходимой информации не было ни в глобальной сети Internet, ни на электронных носителях, то сейчас в эпоху цифровых технологий, оценщик тратит гораздо меньше времени на поиск нужной информации, а также на анализ параметров земельного участка. Объясняется это тем, что в настоящее время существует и функционирует Публичная кадастровая карта, выписку из ЕГРН можно запросить в электронном виде на официальном сайте Росреестра, существует множество сайтов по рынку земельных участков и т. д.

Серьезный вектор развития и перспектив заложен в вычислительную технику - в ближайшем будущем будут создаваться новые методы оценки, основываясь на математически-финансовых базисах и алгоритмах или же на эвристическом анализе введенных данных, а многие процессы станут автоматизированы и не будут требовать вмешательств оценщика. Стоит отметить, что и скорость передачи информации, несомненно, возрастет, что значительно сократит время, потраченное на оценку земельного участка.

Земля является одним из главнейших природных ресурсов и ее можно использовать в целях государства, а также для личного использования или коммерческого. Поэтому на современном этапе уже существует множество предпосылок для разработки единой методологии оценки земельных участков.

\section{БИБЛИОГРАФИЧЕСКИЙ СПИСОК}

1. Федеральный закон "Об оценочной деятельности в Российской Федерации": от 29.07.1998 N 135- Ф3// КонсультантПлюс [Электронный ресурс].

2. Авдюничева Ю. А. Государственная регистрация сделок с недвижимостью на современном этапе развития законодательства в Российской Федерации // Экономика и право. XXI век, 2016. - 92-95 с.

3. Варламов А. А. Земельный кадастр. В 6 томах. Том 5. Оценка земли и иной недвижимости / А. А. Варламов, А. В. Севостьянов. - М.: КолосС, 2015. - 154 с. 
4. Исмагилов Р. Ф., Курзенин Э. Б., Числов А. И. Недвижимость как объект гражданских прав // Мир политики и социологии, - 2015. - 118 с.

5. Ивчатова Н. С. Оптимизация технологических процессов в федеральной службе государственной регистрации, кадастра и картографии и федеральной кадастровой палате при создании единой учетно-регистрационной системы // Известия высших учебных заведений. Геодезия и аэрофотосъемка, 2015. № S5. - С. 160-165.

6. Козлов Д. В. Общая характеристика нового федерального закона «о государственной регистрации недвижимости» от 13.07.2015 № 218-Ф3 // Таврический научный обозреватель, 2015. № 5-1. - 60 c.

7. Липски С. А. Правовое обеспечение землеустройства и кадастров: Учебник. / Липски, С. А., Гордиенко И. И., Симонова К. В. - М.: КноРус, 2016. - 321 с.

(C) Н. К. Шевелев, Е. В. Убоженко, 2021 